УДК 620.91-620.93

DOI https://doi.org/10.15673/swonaft.v84i1.1868

\title{
ОСНОВНІ АСПЕКТИ ПРОЦЕСІВ ТЕПЛОАКУМУЛЮВАННЯ
}

\author{
Демченко В.Г., канд. техн. наук., с.н.с., \\ Коник А.В., канд. техн. наук., с.н.с. \\ Інститут технічної теплофізики НАН України, м. Київ
}

\begin{abstract}
Анотація. Системи та обладнання для зберігання теплової енергї̈ є ключовими елементами при розгортанні відновлюваної теплової енергетики, актуальність якої на даному етапі розвитку набуває масштабного значення. Представлена стаття охоплює короткий аналіз сучасного стану основних технологій інтенсифікації процесів збереження теплоти, аналіз основних технологічних, технічних аспектів, що виникають при розробичі теплових акумуляторів та за реальних умов їх експлуатації. Зокрема, обтрунтовано доцільність застосування теплового акумулювання, проаналізовано иляхи підвищення ефективності економії енергії, визначено основні аспекти процесів акумулящї теплоти.

При обтрунтуванні доиільності застосування теплового акумулювання проаналізовано співвідношення поверхні та об'єму теплового акумулятора, щзо тісно пов'язані з розмірами складових елементів та продуктивністю системи зберігання теплоти. Це співвідношення теоретично вказує, як можливо підвищити коефіцієнт корисної дії та продуктивність систем зберігання теплової енергії. Доведено підвищення ефективності та економії енергії при врахуванні сезонних факторів та пікових навантажень. Розглянуто основні аспекти технологічної інтенсифікації процесів акумуляції теплоти, які полягають у подоланні теплової стратифікації рідинних теплових акумуляторів, обтрунтуванні модульного дизайну конструкції, посиленні передачі теплоти та маси, а також в зміні властивостей матеріалу при фазовому переході.

Розглянуті аспекти при їх реалізації дозволяють оптимізувати роботу генеруючого обладнання з максимально можливим ККД системи теплопостачання, шляхом вирівнювання графіку навантаження у співвідношенні «генерація - споживання», а також розвантажити технологічне обладнання, знизити споживання паливно-енергетичних ресурсів. Як наслідок, знижується собівартість отриманої енергії та зменшуються шкідливі викиди в оточуюче середовище.
\end{abstract}

Ключові слова: система, зберігання теплової енергії, тепловий акумулятор.

\section{MAIN ASPECTS OF HEAT STORAGE PROCESSES}

\author{
Demchenko V.G., PhD, Konyk A.V., PhD \\ Institute of Technical Thermophisics the National Academy of Sciences of Ukraine, Kyiv
}

\begin{abstract}
Systems and equipment for thermal energy storage are key elements in the deployment of renewable thermal energy, the relevance of which at this stage of development is gaining momentum. The presented article covers a brief analysis of the current state of the main technologies of intensification of heat storage processes, analysis of the main technological and technical aspects that arise during the development of heat accumulators and under real conditions of their operation. In particular, the expediency of the application of heat accumulation is substantiated, the ways of increasing the efficiency of energy saving are analyzed, the main aspects of heat accumulation processes are determined.

When substantiating the feasibility of using heat storage, the ratio of the surface and volume of the heat accumulator, which are closely related to the size of the components and the performance of the heat storage system, was analyzed. This ratio theoretically indicates how it is possible to increase the efficiency and productivity of thermal energy storage systems. The increase of efficiency and energy savings taking into account seasonal factors and peak loads has been proved. The main aspects of technological intensification of heat accumulation processes are considered, which consist in overcoming thermal stratification of liquid heat accumulators, substantiation of modular design, strengthening of heat and mass transfer, as well as in changing material properties during phase transition.

The considered aspects at their realization allow to optimize work of the generating equipment with the maximum possible efficiency of system of heat supply. This is achieved by equalizing the load schedule in the ratio "gen-
\end{abstract}


eration - using", and also allows you to unload process equipment, reduce consumption of fuel and energy resources and, as a result, reduces the cost of energy and reduces harmful emissions into the environment.

Key words: system, storage of thermal energy, heating storage.

Формулювання проблеми. Швидкий розвиток інформаційних технологій та промисловості вимагає негайних змін в підходах до реалізації тепло- та енергопостачання. Останні десятиліття активно розвиваються SMART GRID системи теплопостачання 4 та 5 поколінь [1-4]. Основними перевагами яких є:

- використання широко спектру джерел енергії включаючи: теплові насоси, вторинні теплові енергоресурси (ВТЕР), відновлювальну енергетику тощо;

- висока стабільність роботи теплових мереж та енергетичної системи;

- застосування низькотемпературних режимів теплозабезпечення. Очікується, що низькотемпературні системи зберігання тепла 3 температурою теплоносія від 30 до $70{ }^{\circ} \mathrm{C}$ будуть широко застосовуватися в сучасних енергетичних мережах;

- висока степінь автоматизації процесів, зокрема створення інтелектуального управління системою.

За даними агентства Bloomberg частка вітрової та сонячної енергії в структурі світової енергетики подвоїлась за останні 5 років. Проаналізувавши генерацію електрики в 48 країнах, на які приходяться 83\% світової енергії, встановлено, що частка сонячної і вітрової енергії в першому півріччі 2020 року збільшилась на $14 \%$ у порівнянні з минулим роком [5]. Україна у червні поточного року збільшила виробництво електроенергії з відновлюваних джерел в порівнянні з аналогічним періодом минулого року на $5,5 \%$, загалом до 17 \% [6]. У майбутньому планується використовувати продукти перероблювання твердих фракцій біомаси в біогаз або синтез-газ, різні види рідкого біопалива з метою його транспортування. За даними [7], четверте покоління централізованого опалення (ЦО) має бути впроваджено вже у період 2020 - 2050 роках.

Використання та розвиток джерел відновлюваної енергії у теплоенергетиці значно зменшує залежність від викопних видів палива та вплив шкідливих викидів на навколишнє середовище. Однак ці джерела енергії значно віддалені від споживача, або мають переривчатий характер у часі [1,9]. Забезпечення стабільності роботи системи можливо за допомогою теплових акумуляторів (ТА). Адекватне застосування яких дозволяе уникнути колосальних теплових втрат, що сягають 60 \% на сьогоднішній день при теплопостачанні трубопроводом ЦО. Так, в мережах ЦО теплові акумулятори можуть здійснювати наступні завдання: компенсація піків споживання теплової енергії; вирівнювання (оптимізація) графіків виробництва теплоти шляхом накопичення надлишкової теплової енергії, яка буде використана під час відключення (відсутності) енергопостачання тощо. Таким чином, частка використання енергії в загальному річному споживанні може досягати $100 \%$.

Задачі. Теплове акумулювання переживає стрімкий розвиток в країнах Євросоюзу, США, Китаї та Японії, роботи за напрямком підтримуються на законодавчому рівні і фінансуються з державного бюджету та приватним бізнесом. В Україні проводяться окремі пілотні проекти, які на даний час не мають системного характеру, тому необхідно використовуючи закордонний досвід адаптувати та модернізувати діюче теплове обладнання для подальшого розвитку і впровадження нових технологій. В статті пропонується проаналізувати основні технологічні, технічні аспекти, які виникають в процесі розробки та за реальних умов експлуатації ТА, що впливають на інтенсифікацію процесів зберігання теплоти. Для досягнення поставленої мети сформульовано наступні завдання:

- розглянути шляхи підвищення ефективності економії енергії;

- обгрунтувати доцільність акумуляції теплоти;

- визначити шляхи інтенсифікації процесів акумуляції теплоти.

Під поняттям «теплового акумулювання» розуміють перебіг фізичних або хімічних процесів, за допомогою яких відбувається накопичення теплоти. Акумулююча система характеризується способом відбору енергії від джерела для зарядки акумулятора, трансформацією (при необхідності) в необхідний вид енергії та віддачою енергії споживачу. Теплові акумулятори призначені для зберігання теплової енергії на різних етапах теплопостачання. В залежності від принципу дії за яким працюють ТА, розрізняють - біологічні, хімічні, термохімічні, термічні, стисненого повітря, магнетичні та механічні $[8,9]$. ТА, як правило, складається 3 резервуара для зберігання, акумулюючого середовища (робочого тіла), устаткування для заряджання та розрядження і допоміжного обладнання. Технологічно акумулятори теплоти розрізняють:

1. за періодом заряджання і розрядження:

- короткострокові ТА (до 3 днів);

- середньострокові ТА (до 1 місяця);

- довгострокові ТА;

2. за рівнем робочої температури:

- низькотемпературні ТА (до $120^{\circ} \mathrm{C}$ );

- середньотемпературні ТА (від 120 до $400^{\circ} \mathrm{C}$ ); 
- високотемпературні ТА (понад $400{ }^{\circ} \mathrm{C}$ ).

Застосовуючи перший закон термодинаміки для підведеної та відведеної енергії до відкритої системи, можна представити баланс енергії для процесу акумуляції в загальному вигляді:

$$
E_{\text {ак }}=E_{\mathrm{Bx}}-E_{\text {вих }}
$$

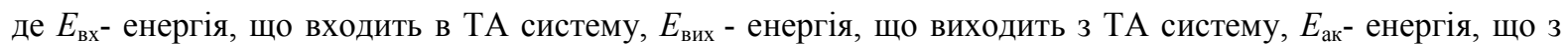
акумулювалася в системі.

Дослідження загального рівняння (1) показує, що акумулювання енергії може здійснюватися в результаті зміни: питомої внутрішньої енергії, питомої потенційної енергії, питомої кінетичної енергії та маси системи. До теплового акумулювання енергії зазвичай відносять питому внутрішню та потенційну енергії.

Відповідно до проведеного аналізу пропонується, наступна класифікація ТА, з урахуванням класичного підходу викладеного у [10]:

1) Акумулююча і теплообмінна здатність теплоакумулюючого матеріалу (ТАM):

1.1. Пряме акумулювання: акумулююча речовина в якій відбувається теплообмін протікає в одному середовищі. Акумулююче середовище може бути твердим, рідким, газоподібнім або двофазним;

1.2. Непряме акумулювання - енергія акумулюється тільки за допомогою теплообміну (наприклад, теплопровідністю через поверхню теплообміну) або в результаті масообміну спеціального теплообмінного середовища (в рідкому, двофазному або газоподібному стані);

1.3. Напівпряме акумулювання - процес протікає як у п. 1.2., за винятком того, що акумулююча ємність теплообмінного середовища має більш важливу роль (наприклад, акумулювання гарячої нафти);

1.4. Сорбційне акумулювання - використовується здатність деяких середовищ абсорбувати гази 3 виділенням теплоти і поглинанням теплоти при десорбції газу.

2) Маса акумулюючого середовища:

2.1. Постійна маса $\left(\mathrm{m}_{\mathrm{a \kappa}}=0\right)$ : зазвичай це випадок непрямого акумулювання. Однак, може мати місце пряме акумулювання, якщо переміщувана частина маси після охолодження (при розрядженні) або нагрівання (при заряджанні) повністю повертається в акумулятор (акумулювання «витіснення»);

2.2. Перемінна маса $\left(\mathrm{m}_{\mathrm{a \kappa}} \neq 0\right)$ : це завжди випадок прямого акумулювання.

3) Об'єм акумулятора:

3.1. Постійний об'єм ( $\left.\mathrm{V}_{\text {ак }}=0\right)$ : відповідає процесу акумулювання в закритих ємностях;

3.2. Змінний об'єм $\left(\mathrm{V}_{\text {ак }} \neq 0\right)$ : відповідає процесу акумулювання при атмосферному тиску або зі спеціальним компресорним обладнанням.

4) Тиск в акумуляторі:

4.1. Постійний тиск $\left(\mathrm{dP}_{\text {ак }}=0\right)$;

4.2. Змінний тиск $\left(\mathrm{dP}_{\mathrm{a \kappa}} \neq 0\right)$.

Шляхи підвищення ефективності економії енергії. Для економії енергетичних ресурсів, необхідно переформатувати народногосподарську концепцію користування, з метою знизити енергоємність національного продукту. Досягнути цього можливо двома шляхами [11].

Перший шлях пов'язаний з підвищенням ефективності перетворення первинної енергії в електроенергію і теплоту. Це стосується підвищення ККД тепло- електростанцій, перехід на більш дешеві види палива, збільшення частки атомних електростанцій та використання поновлюваних джерел енергії, тощо.

Другий шлях - це підвищення ефективного використання енергії, безпосередньо у споживачів - в промисловості, транспорті, сільському господарстві та в побуті [12]. Великі резерви цієї енергії дозволяють економити енергоресурси, часто при значно менших витратах, ніж при генерації енергії. Відомо, що витрати на заходи для економії палива та електроенергії, в будь якому випадку будуть в 2-3 рази нижчі за витрати залучені на розширення паливно-енергетичної бази. До таких заходів можна віднести перехід на вдосконалені і сучасні енергозберігаючі технології, використання вторинних енергетичних ресурсів та застосування місцевих видів палив. А також, вирівнювання добових і сезонних невідповідностей між виробленою енергією і потребами в ній, за рахунок застосування акумулювання енергії.

Обгрунтування економічної доцільності акумуляції теплоти. У період зимового піку навантаження ТА дає економію капітальних витрат, дозволяючи використовувати базисні установки меншої потужності. А також, знижує витрати на паливо завдяки меншої тривалості роботи в пікових періодах.

У період, характерний для середини літа, порівняно небагато використовується пікової енергії (вище лінії розташування базового навантаження) [10]. При цьому ТА дає економію вартості палива пікової енергії. Шляхом зупинки частини котельного обладнання, досягається економія вартості палива. 


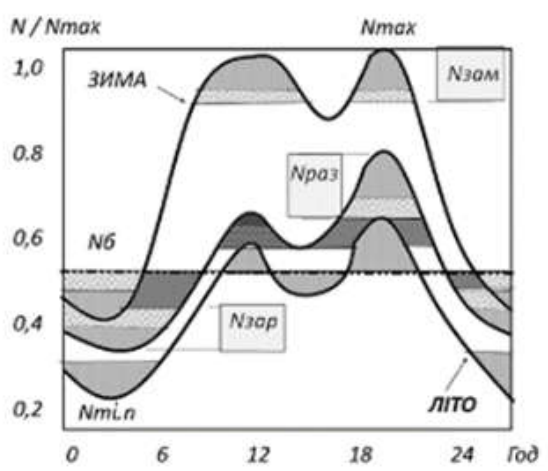

Рис. 1 - Характерні графіки добового навантаження

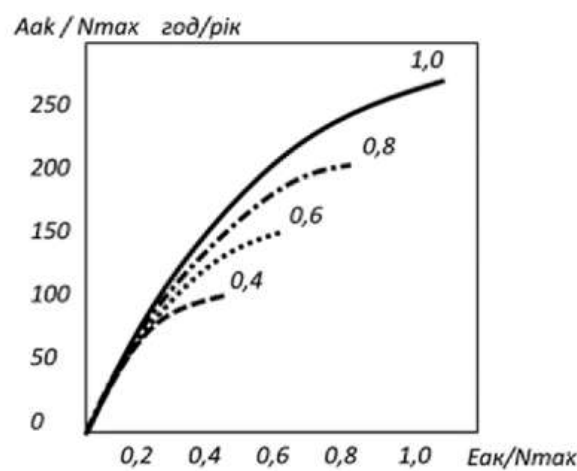

Рис. 2 - Залежність відносної річної акумульованої енергії $\mathrm{A}_{\text {aк }} / \mathbf{N}_{\max }$ до співвідношення $\mathbf{E}_{\mathrm{ar}} / \mathbf{N}_{\max }$

На рис. 1, праворуч, показана тривалість можливого використання ТА (в припущенні його 100 \% ефективності) при максимальному навантаженні $N_{\max }$. Для згаданих вище випадків вона складає 0,$4 ; 0,2$ i 1,0 год, відповідно. Максимальна можливість використання ТА настає в періоди рівноваги.

Відзначимо характерні переваги акумуляторів різної ємності в кожному окремому випадку:


наприклад в середині зими;

б) максимальну потужність розрядженні $N_{\text {роз }}$ в період рівноваги або близький до нього;

в) максимальну потужність зарядки $N_{\text {зар }}$ в період рівноваги або близький до нього.

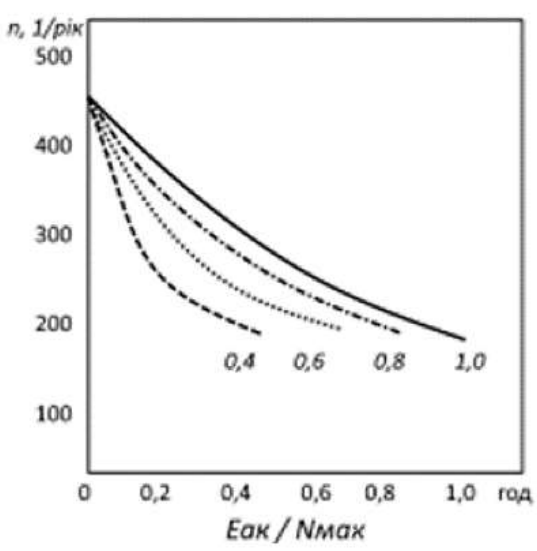

Рис. 3 - Число розряджень за рік $n$ в залежності від відносної ємності ТА

Наочно переваги характеристик використання акумуляторів показано на рис. 2, внаслідок режиму зміни вихідних і робочих днів, який вносить додаткову періодичність в споживання тепла.

3 аналізу характеристик добових навантажень за рік, представлених кривими для спеціальних випадків на рис. 2, може бути знайдена величина відносної річний акумульованої енергії $A_{a \kappa} / N_{\max }$, виміряна в годинах максимального навантаження за рік. Вона представлена на рис. 2 в залежності від $\mathrm{E}_{\text {ак }} / \mathrm{N}_{\text {max }}$, де $E_{\text {ак }}$ позначає повну встановлену ємність акумулятора в системі.

На рис.3 показано число розряджень $n$ за рік в залежності від $E_{a \kappa} / N_{\max }$ для різних значень ефективності акумуляторів (при декількох теплоакумулюючих установках в системі $\mathrm{E}_{\mathrm{a \kappa}}$ позначає їх загальну ємність, а $n$ - середнє число розряджень).

Технологічна інтенсифікація процесів. Технології інтенсифікації процесів (ТІП) в основному характеризуються,

щонайменше, одним із наступних трьох елементів:

- збільшення теплопередачі та маси;

- зменшення розмірів;

- застосування модульної конструкції.

Підвищення теплопередачі досягається головним чином шляхом збільшення значення співвідношення внутрішньої поверхні теплообміну до об'єму накопичення. Низькотемпературні системи зберігання теплоти, що використовують матеріали з фазовим переходом, можуть досягати високої потужності заряджання / розрядження $[15,16]$. Наприклад, у сезонних акумуляторах теплової енергії за допомогою матеріалу з фазовим переходом критичним завданням $є$ контроль переохолодження під час зміни фази.

Зменшення розмірів ТА, забезпечує точне управління процесом та оптимальне управління потоками енергії. А також, дає можливість проектування ТА з уніфікованих елементів будь-якої потужності, що позитивно впливає на вартість обладнання та експлуатаційні витрати.

Модульне розташування системи ТА дає можливість створення гнучкої теплової інтелектуальної сітки. Також, роботу ТА із модульною системою можливо математично з прогнозувати [13].

Сучасна система зберігання теплової енергії використовує наступні основні аспекти - технології інтенсифікації процесів, зменшення розмірів обладнання, модульну інтеграцію, зменшення теплових втрат та кращі показники економії ресурсів. 
Модульна конструкція. ТА з високою місткістю вимагає великих обсягів зберігання, що призводить до низьких втрат енергії через ізоляцію. Це описує рівняння 2, в якому кількість втрат теплоти $Q_{\text {втр }}$ залежіть від коефіцієнта втрат тепла крізь ізоляцію $k$, який кратний різниці температур між акумулятором та довкіллям. Збережена теплова енергія $Q_{3 б}$ для ємнісного ТА може бути оцінена шляхом множення щільності та тепломісткості накопичувального середовища на об'єм зберігання теплоти, а також різниці температур між

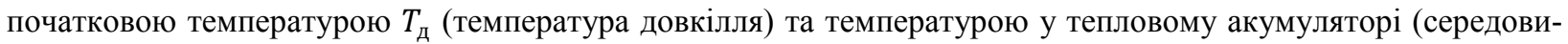
ще зберігання) $T_{3 б}$. Тому, втрату енергії $\varepsilon$ можна виразити наступним рівнянням:

$$
\varepsilon=\frac{Q_{\text {втр }}}{Q_{\text {зб }}}=\frac{\left(k \cdot S_{\text {із }}\left(T_{\text {зб }}-T_{\text {д }}\right)\right)}{\rho \cdot C_{p} \cdot V_{\text {зб }}\left(T_{3 б}-T_{\text {д }}\right)}=\frac{k}{\rho \cdot C_{p}} \cdot\left(\frac{S_{\text {із }}}{V_{\text {зб }}}\right)
$$

Питома втрата енергії $\varepsilon$ залежить від співвідношення $\frac{S_{\text {is }}}{V_{36}}$, що представляє відношення площі огороджувальної ізольованої поверхні до об’єму сховища. Це співвідношення зменшується при збільшенні об'єму ТА [14]. Вважливе питання - швидкість заряджання та скидання теплової енергії, особливо для систем непрямого зберігання. Питома швидкість заряджання наведена в рівнянні 3 , де $S_{\text {внт }}$ являє собою внутрішню поверхню теплообміну між робочим тілом (теплоносієм) і середовищем зберігання (ТАM).

Співвідношення - внутрішньої площі теплопередачі до об'єму зберігання $\frac{S_{\text {внт }}}{V_{3 б}}$ безпосередньо позитивно впливає на швидкість зарядження ТА, де $\alpha$ - коефіцієнт теплообміну між теплоносієм та акумуляційною рідиною (водою) в ємності акумулятору.

$$
\hat{\mathrm{c}}=\frac{Q_{\mathrm{a \kappa}}}{Q_{\text {зб }}}=\frac{\alpha}{\rho \cdot C_{p}} \cdot \frac{\left(T_{\mathrm{TH}}-T_{3 б}\right)}{\left(T_{\text {зб }}-T\right)} \cdot \frac{S_{\mathrm{BHT}}}{V_{\text {зб }}}
$$

Слід зазначити, що ідеальні системи ТА повинні мати характерну високу швидкість заряджання та розрядження $\hat{c}$.

Теплова стратифікація. Теплова стратифікації - це явище пошарової диференціації температури, що виникає у вертикальному резервуарі в наслідок природної конвекції. Добре стратифікований резервуар для зберігання теплоти підтримує тонкий шар, який розділяє холодну і гарячу зони, цей шар називається «термоклином». Температура теплоакумулюючої рідини має високий градієнт виключно в цьому шарі.

Три основні механізми передачі теплоти:

- дифузія теплоти між сусідніми шарами, включаючи ті, що знаходяться в рідині та через огороджувальну конструкцію ємності;

- примусова конвекція, що виникає в наслідок перемішування рідини, шляхом рециркуляції потоку або локальної турбулентності;

- природна конвекція, що зумовлена плавучістю.

Щоб посилити теплову стратифікацію, слід посилити природну конвекцію, а вплив перших двох механізмів мінімізувати.

У ТА невеликого розміру та великих системах застосовуються технології, що спрямовані на мінімізацію турбулентності. Для резервуарів рекомендується передбачити впускний отвір з малим потоком, що забезпечить меншу гідравлічну турбулентність. Реалізується таке рішення, за допомогою дифузора на вході.

У випадках, коли витрата вхідного потоку має підтримуватися на високому рівні, для використання переваги потоку, орієнтованого на плавучість, застосовується спеціальна диспозитивність. Яка включає клапани, що залежать від щільності, теплові діоди або «теплове ядро» $[15,16]$. Для установок значних розмірів, застосовують спеціальні впускні колектори з регульованим положенням на вході, відповідно до вертикального профілю температури для гарантування зручності використання енергії.

Висновки. Активне використання відновлювальних джерел енергії потребує розвитку систем зберігання теплової енергії, щоб мінімізувати теплові втрати на всіх етапах теплозабезпечення. Теплові акумулятори та системи зберігання теплової енергії розрізняються за технологічними параметрами і принципами дії, тому вірно підібране, відповідно до умов експлуатації, обладнання дозволить не лише суттєво економити ресурси, але позитивно позначиться на екології навколишнього середовища.

В результаті проведеного аналізу авторами статті запропоновано при розробці сучасних систем зберігання теплової енергії застосовувати технології інтенсифікації процесів, що дозволяють створювати модульне обладнання відносно невеликих геометричних розмірів з високою здатністю до інтеграції в діючі теплові мережі. Необхідно зауважити, що в перехідний період до SMART GRID системи 4 та 5 покоління TA модульної конструкції не втратять своєї економічної доцільності, а застосування акумулюючих речовин 3 фазовим переходом та псевдопластичних рідин дозволить вирішити питання акумулювання та збереження теплоти на новому рівні. 
Окремої уваги, заслуговує проблема вирівнювання пікових навантажень за допомогою ТА, що дозволяє суттєво знизити витрати на енергоресурси та покращити економічні показники системи зберігання теплової енергії.

\section{References}

1. Lund, H., Werner, S., Wiltshire, R., Svendsen, S., Thorsen, J. E., Hvelplund, F., et al. (2014). 4th Generation District Heating (4GDH): integrating smart thermal grids into future sustainable energy systems. Energy $68,1-$ 11. DOI:10.1016/j.energy.2014.02.089

2. Thermal Energy Storage. Technology Brief. IEA-ETSAP and IRENA Technology Brief E17, 24.

3. Stiles, L., Gitchell, A., Hulse, D. (2003). Hiller Underground Thermal Energy Storage in the United States. 9th International Conference on Thermal Energy Storage. Warsaw, POLAND, 651-656

4. Struhala, K., Ostrý, M., Bantová, S. (2019). Environmental Assessment of Latent Heat Storage Technology. IOP Conf. Series: Earth and Environmental Science, 290. 012087 DOI:10.1088/1755-1315/290/1/012087

5. Dolya energii vetra i solntsa v globalnoy energetike udvoilas za pyat let, Bloomberg/ BiznesTsenzor. Retrieved from https://mbiz.censor.net.ua/news/3213641/dolya_energii_vetra_i_solntsa_v_globalnoyi_energetike_udvoil as_za pyat_let_bloomberg

6. Za rik Ukraina zbilshyla vyrobnytstvo elektroenerhii z VED na 5,5\% / Ahrobiznes sohodni. Retrieved from http://agro-business.com.ua/agrobusiness/item/18488-za-rik-ukraina-zbilshyla-vyrobnytstvoelektroenerhii-z-ved-na-5-5protsent.html

7. Nort, D. (1997). Instituty institutsionalnyye izmeneniya i funktsionirovaniye ekonomiki. M.: Fond ekonomicheskoy knigi «Nachala».

8. Shahid, A., Deshmukh, S.P. (2020). An overview: Applications of thermal energy storage using phase change materials. Article in Materials today: proceedings May. DOI: 10.1016/j.matpr.2020.02.247

9. Cabeza, L.F. and other (2015). Introduction to thermal energy storage (TES) systems. Advances in Thermal Energy Storage Systems. Methods and Applications. Woodhead Publishing Series in Energy, 1-28 https://doi.org/10.1533/9781782420965.1

10. Bekman, G., Gilli, P. (1987). Teplovoe akkumulirovanie energii. Per. s angl. pod red. d.t.n. Brodyanskogo V.M. M.: Mir.

11. Fortunato, B. A. (2016). Combined power plant fueled by syngas produced in a downdraft gasifier. In Proceedings of the ASME Turbo Expo. Seoul, South Korea, 3. DOI: 10.1115/GT2016-58159.

12. Short, M., Crosbie, T., Dawood, M. and Dawood, N. (2017). Load forecasting and dispatch optimization for decentralized co-generation plant with dual energy storage," Appl. Energy, 186 (3), 304-320. doi: 10.1016/j.apenergy.2016.04.052.

13. Demchenko, V.H., Hron, S.S., Pohorielova N.D. (2019). Konstruktorskyi rozrakhunok mobilnoho teplovoho akumuliatora. Teplofizyka ta teploenerhetyka, 41(4), 35-43. doi https://doi.org/10.31472/ttpe.4.2019.5

14. Roskilly, A., Yan, J. (2017). Sustainable thermal energy management. Appl. Energy, 186 (3), 249-250. DOI: 10.1016/j.apenergy.2016.10.113.

15. Demchenko, V.G., Tselen, B.J., Konyk, A.V., Ivanov, S.O. (2020). Research of thermal cycling of organic substances with phase transition. Praha, Czech Republic. "Scientific discussion», 1(41), 54-58.

16. Demchenko, V.G., Konyk, A.V. (2020). Research of heat accumulation capacity binary water systems https://doi.org/10.9790/5736-1306010107

Отримано в редакцію 03.07.2020

Прийнято до друку 09.10.2020
Received 03.07.2020

Approved 09.10.2020 